\title{
SURVIVAL OF BLOOD GROUP FACTORS AFTER DEATH
}

\author{
BY \\ J. B. ENTICKNAP \\ From East Ham Memorial Hospital, London
}

(RECEIVED FOR PUBLICATION OCTOBER, 1956)

The tissues of the body decompose at different rates after death, but little is known of how long red cell antigens persist in the cadaver, this despite the data available on the decay of agglutinins in stored blood samples and on the appearance of false antibodies and panagglutinability when they become infected (Thomsen, 1927 ; Steffan, 1932). Latterly the stability of red cell agglutinogens in vitro has also been studied (Mourant, 1951) and reports of false agglutinogens in stored blood have appeared (Fruin, 1946). Grouping of forensic blood stains is known to be trustworthy, but for investigation of transfusion reactions at necropsy whole red cells must be used. The present investigation shows that tests on red cells obtained from the body after death give reliable results.

\section{Materials and Methods}

Cadaver blood from 100 patients who had been grouped during life but had not been transfused shortly before death was examined. Samples, which were usually fluid, were collected without anticoagulant or sterile precautions from a major vein at necropsy. Many of the cadavers had been refrigerated at $7^{\circ} \mathrm{C}$. and necropsies were made between three and 140 hours after death (mean, 35 hours; S.D., 46 ; log-normal distribution). Washed red cell suspensions were all tested in tubes (Mollison, Mourant, and Race, 1948) within 48 hours and most of them within one hour of collection. National Blood Transfusion Service sera were used with saline or albumin anti-D as available and the results were read both macroscopically and microscopically. Thirty-five of the postmortem samples were also tested with human serum from a group AB subject and 12 with Coombs serum.

\section{Results}

Most of the deaths were due to malignant disease or had followed operations ; one was due to bacterial endocarditis and many had other infections. From four cadavers in which generalized clostridial infection developed, and from one immersed for three weeks, no intact cells could be obtained.

On none did the observed blood group appear to change in the interval between ante- and postmortem testing.
None of the cells tested agglutinated with AB serum and no positive direct Coombs reactions occurred. The ABO and $\mathrm{Rh}(\mathrm{D})$ group frequencies were similar to those obtaining in the general British population (Table).

DISTRIBUTION OF BLOOD GROUPS AMONG THE CASES

\begin{tabular}{cc|c|c|c}
\hline & & $\begin{array}{c}\text { Rh(D) } \\
\text { Positive }\end{array}$ & $\begin{array}{c}\text { Rh(D) } \\
\text { Nogative }\end{array}$ & Percentage \\
\hline Group O &. & 41 & 5 & 46 \\
", A &. & 38 & 5 & 43 \\
,$"$ AB & $\ldots$ & 5 & 1 & 6 \\
\hline Percentage &.. & 5 & 0 & 5 \\
\hline
\end{tabular}

\section{Discussion}

It is clear that standard techniques will determine the $A B O$ and $R h(D)$ groups of red cells from the cadaver, even those extracted many hours after death, and that the results agree with those given by tests on the same patients during life. Nonspecific reactions are infrequent; in particular cells from the three AB Rhesus-positive subjects tested did not agglutinate with homologous serum. The material came from four hospitals and a public mortuary over a period of five years and so was fairly representative of necropsies in this country.

If red cells can be obtained from the cadaver they may be used for blood grouping with reasonable confidence.

The investigation is being continued to exclude the occurrence of degradation or of panagglutinability in a small proportion of cadaver blood samples.

\section{Summary}

The $A B O$ and $R h(D)$ blood groups of 100 postmortem samples of blood were the same as the groups assigned to the patients while still alive.

\section{REFERENCES}

Fruin, R. L. (1946). Amer. J. clin. Path., 16, 405. Mollison, P. L., Mourant, A. E., and Race, R. R. (1948). Med. res. Coun. Memo. No. 19.

Mourant, A. E. (1951). Personal communication. Steffan, P. (1932). Handbuch der Blutgruppenkunde. Lehmann,
Munich.

Thomsen, O. (1927). Z. ImmunForsch. (Orig.), 52, 85. 